\title{
Look what the cat dragged in: Felis silvestris catus as predators of insular bats and instance of predation on the endangered Pipistrellus maderensis
}

\author{
RICARDO ROCHA ${ }^{1,2}$ \\ ${ }^{1}$ Centre for Ecology, Evolution and Environmental Changes \\ Faculty of Sciences, University of Lisbon, 1749-016 Lisbon (Portugal). \\ ${ }^{2}$ Metapopulation Research Centre \\ University of Helsinki, PO Box 65 (Viikinkaari 1), FI-00014 Helsinki (Finland). \\ *Corresponding author e-mail:_ricardo.nature@gmail.com
}

DOI: http://dx.doi.org/10.14709/BarbJ.8.1.2015.04 (C) 2015 Published by SECEMU.

Spanish title: Felis silvestris catus como predador de murciélagos insulares y cita de depredación sobre el amenazado Pipistrellus madeirensis.

\begin{abstract}
This note reports the predation of a threatened Madeira pipistrelle bat by a domestic house cat. This represents the first confirmed record of cat predation upon a Macaronesian bat and adds to an increasing body of evidence suggesting that free-ranging cats pose a strong negative impact to native insular vertebrate populations.
\end{abstract}

Keywords: bats, domestic cats, non-native species, Madeira pipistrelle, Macaronesia.

The impact of non-native species is one of the most influential forces underpinning the global biodiversity crisis (Nogales et al. 2013, Dirzo et al. 2014). Since the domestication of the African wildcat Felis silvestris lybica some 9500 years ago, the domestic counterpart F. s. catus (Fig. 1) has become one of the world's most abundant and widespread pets and has established feral populations in both continental and island ecosystems (Driscoll et al. 2007).

Free-ranging cats are generalist and opportunistic predators that tend to proliferate around human populated areas, with detrimental effects on a wide array of native taxa (Woods et al. 2003, Bonnaud et al. 2011, Loss et al. 2013). Their impacts are especially pervasive in insular ecosystems where they ultimately function as superpredators because most species have evolved in the absence of mammal predation (Blackburn et al. 2004). At least 175 insular vertebrate species have been driven to extinction or are threatened as a result of the introduction of this species (Medina et al. 2011). As such, F. s. catus has been included in the 100 worst invasive species list (Lowe et al., 2000) and is considered one of the top 100 terrestrial invasive flora and fauna species of conservation concern in the Macaronesia bioregion (Silva et al. 2008).

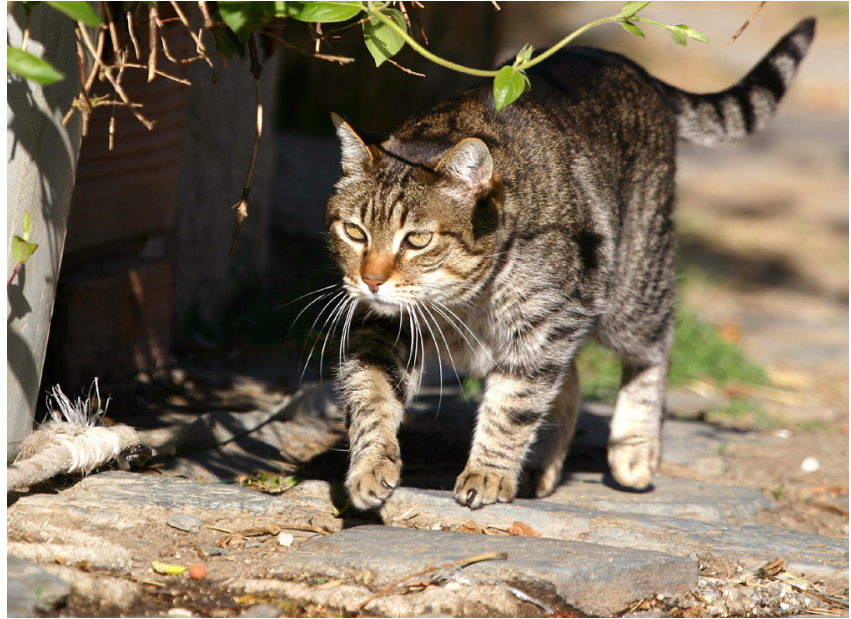

Fig. 1 - Free-roaming domestic cat Felis silvestris catus, Funchal, Madeira.

Mammals are frequently preyed by cats (Woods et al. 2003), though in insular populations this mostly reflects predation upon non-native rodents and lagomorphs (Nogales \& Medina 2009, Millan 2010, Bonnaud et al. 2011). Bats are 


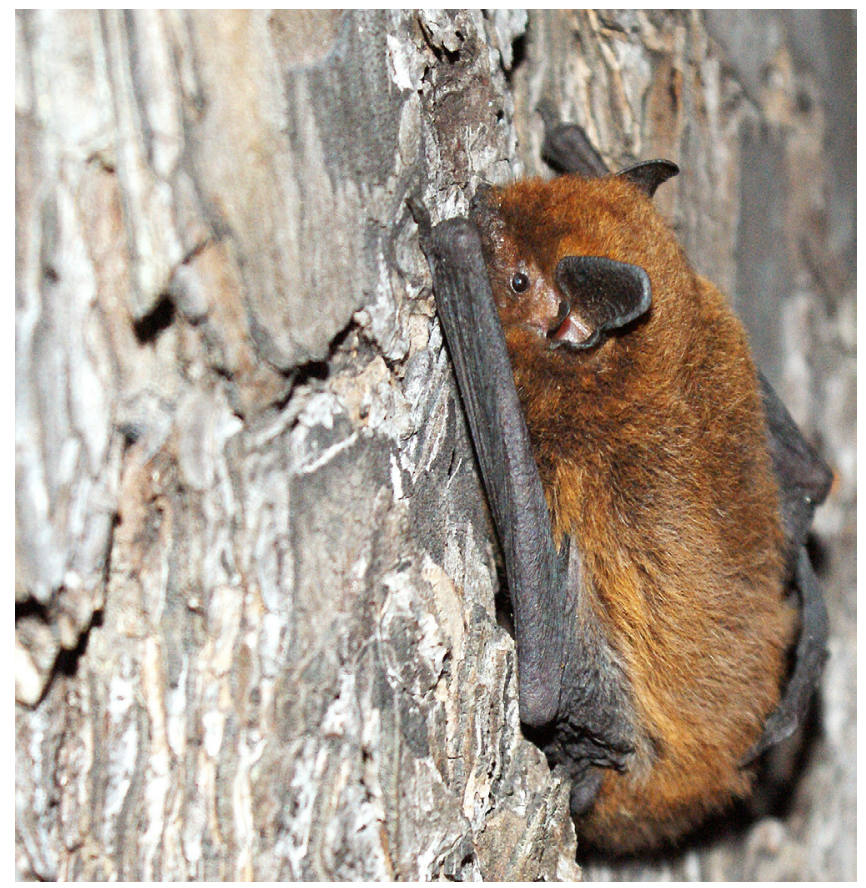

Fig. 2 - Adult Madeira pipistrelle Pipistrellus maderensis, Porto Moniz, Madeira.

common in human-made structures and co-occur with cats in many island ecosystems worldwide; however, reports of cat predation on insular bats are scarce (Bonnaud et al. 2011 but see Rodríguez-Durán et al. 2010 and Scrimgeour et al. 2012).

The Madeira pipistrelle Pipistrellus maderensis (Fig. 2) is a small vesper bat known to occur in the Macaronesian archipelagos of Madeira and Canary (Jesus et al. 2013) and possibly on some Azorean islands (Rainho et al. 2002). Due to its reduced area of occurrence and presumed decreasing population size, this is one of the most threatened European bat species, thus being currently classified as endangered according to the IUCN Global Red List (Juste et al. 2008) and critically endangered according to the Portuguese Red Book of Vertebrates (Queiroz et al. 2005). Predation by non-native mammals, including cats, has been suggested as a possible threat to P. maderensis (Jesus et al. 2009), however, until now this has not been confirmed. The present note therefore provides evidence of the suspected predation of $P$. maderensis by introduced cats, reporting an instance of domestic cat predation on an adult bat in Madeira Island, Portugal.

On $21^{\text {st }}$ December 2014 a female adult domestic cat brought home a recently killed adult Madeira pipistrelle (forearm $=33 \mathrm{~mm}$; tibia $=12.5 \mathrm{~mm}$ ). The bat presented a ventral wound under the right arm and a single perforation to the right wing. The house was located in an urban area (32.6565, -16.9079) in Madeira's capital, Funchal, and the domestic cat was well-fed, wore no bell and had unrestricted access to outdoors. After identification the retrieved bat was deposited at the Funchal Natural History Museum (MMF 44313). Prior to this incident, the same cat had brought home two other bats over the period of less than one year. However, the cat's owner discarded both individuals and the specimens' identity could not be confirmed. The type of injuries and the fact that the cat had already brought home other bats suggests that the instance here reported does not represent an isolated capture of a debilitated bat from the ground but indeed corresponds to predation upon a healthy individual. Individual cats can specialize on particular types of prey (Churcher et al. 1989), including bats (Scrimgeour et al. 2012, Ancilloto et al. 2013). They can thus be potentially very dangerous for the persistence of entire colonies (particularly nursery roosts); the fact that the cat reported in this note already preyed upon other bats is alarming, particularly for a species with small populations.

Domestic cat predation was found to represent a significant threat to bats in the Italian peninsula, where most adult bat admissions to wildlife rescue centres were associated with cat-related injuries (Ancillotto et al. 2013). Furthermore, from a total of 9852 mammal prey items brought home by 986 cats in Great Britain over a 5 month period, $0.2 \%$ belonged to chiropteran species (Woods et al. 2003). Freeranging cats were estimated to kill between 6.9-20.7 billion mammals in the United States, surpassing all other sources of human-induced mortality (Loss et al. 2013). However, this study reported no breakdown of the mammalian prey species, therefore, the true impact of domestic cats in the US on bat populations is still unknown.

Despite the paucity of studies investigating the relationship between cats and bats in insular ecosystems, several insular chiropteran species have been identified as targets of free-roaming cats. In Puerto Rico, cats were found to systematically visit caves harbouring multispecies bat assemblages and scat analyses revealed that at least 5 bat species were regularly consumed by free-ranging felines (Rodríguez-Durán et al. 2010). In this study, and during a period of 8 months, researchers recovered 320 bat wings representing at least 161 individual bats and observed up to 16 cats hunting in the same cave in a single night. In New Zealand a single male cat preyed on at least 102 IUCN vulnerable short-tailed bats Mystacina tuberculata rhyocobia in two colonial roost trees over a 7 day period (Scrimgeour et al. 2012). On Christmas Island, cats were reported to prey on black-eared flying foxes Pteropus melanotus (Bonnaud et al. 2011) and have been suggested to have contributed to the population decline of the presumed extinct Christmas Island Pipistrelle Pipistrellus murrayi (Schulz \& Lumsden 2004, Martin et al. 2012).

Free-roaming cat demographic management combined with initiatives aimed at altering human behaviours that augment the impacts of domestic cats on wildlife populations (e.g. allowing outdoor access or unwanted pet abandonment) would undoubtedly lessen the consequences of cat predation upon native taxa (Miller et al. 2014). Collar-mounted warning devices were suggested to reduce mortality of wildlife by domestic cats (Nelson et al. 2005), though their effectiveness in reducing cat predation upon bats is still to be verified. Further investigation on the magnitude of predation by domestic cats upon insular bats is clearly warranted, and detailed reports of cat kills such as the one here presented are essential for a better understanding of this major but neglected cause of bat mortality. 


\section{ACKNOWLEDGMENTS}

I am extremely grateful to Sasha Vasconcelos for yet another English revision and to José Jesus for providing the photo of a live specimen of Pipistrellus maderensis. I also thank the Portuguese Foundation for Science and Technology for financial support (PhD grant SFRH/BD/80488/2011).

\section{REFERENCES}

Ancillotto, L., Serangeli, M. T. \& Russo, D. 2013. Curiosity killed the bat: Domestic cats as bat predators. Mammalian Biology 78 (5): 369-373. Doi: http://dx.doi.org/10.1016/j.mambio.2013.01.003

Bonnaud, E., Medina, F. M., Vidal, E., Nogales, M., Tershy, B., Zavaleta, E., Donlan, C. J., Keitt, B., Le Corre, M. \& Horwath, S. V. 2011. The diet of feral cats on islands: a review and a call for more studies. Biological Invasions 13 (3): 581-603. Doi: http:// dx.doi.org/10.1007/s10530-010-9851-3

Blackburn, T. M., Cassey, P., Duncan, R. P., Evans, K. L., \& Gaston, K. J. 2004. Avian extinction and mammalian introductions on oceanic islands. Science 305(5692): 1955-1958. Doi: http://dx.doi. org/10.1126/science. 110161

Churcher, P. B. \& Lawton, J. H. 1989. Beware of well-fed felines. Natural History 98:40-47.

Dirzo, R., Young, H. S., Galetti, M., Ceballos, G., IsaAC, N. J. B. \& Collen, B. 2014. Defaunation in the Anthropocene. Science 345 (6195): 401-406. Doi: http://dx.doi.org/10.1126/science.1251817

Driscoll, C. A., Menotti-Raymond, M., Roca, A. L., Hupe, K., Johnson, W. E., Geffen, E., Harley, E. H., Delibes, M., Pontier, D., Kitchener, A. C., Yamaguchi, N., O’Brien, S. J. \& Macdonald, D. W. 2007. The Near Eastern Origin of Cat Domestication. Science 317 (5837): 519-523. Doi: http://dx.doi. org/10.1126/science. 1139518

Jesus, J., Teixeira, S., Teixeira, D., Freitas, T. \& Russo, D. 2009. Vertebrados terrestres autóctones dos arquipélagos da Madeira e Selvagens. Direcção Regional de Ambiente, Funchal, Portugal.

Jesus, J., Teixeira, S., Freitas, T., Teixeira, D. \& Brehm, A. 2013. Genetic identity of Pipistrellus maderensis from the Madeira archipelago: a first assessment, and implications for conservation. Hystrix 24(2): 177-180. Doi: http://dx.doi.org/10.4404/hystrix-24.2-8736

Loss, S. R., WiLl, T. \& Marra, P. P. 2013. The impact of freeranging domestic cats on wildlife of the United States. Nature Communications 4(1): 1396. Doi: http:// dx.doi.org/10.1038/ncomms 2380

Juste, J., Palmeirim, J. M. \& Alcaldé, J. T. 2008. Pipistrellus maderensis. The IUCN Red List of Threatened Species. Version 2014.3. <www.iucnredlist.org>. Downloaded on 28 December 2014.
Lowe, S., Browne, M., Boudjelas, S. \& De Poorter, M. 2000. 100 of the world's worst invasive alien species: a selection from the global invasive species database. Invasive Species Specialist Group Species Survival Commission, World Conservation Union (IUCN), Auckland, New Zealand.

Martin, T. G., Nally, S., Burbidge, A. A., Arnall, S., Garnett, S. T., Hayward, M. W., Lumsden, L. F., Menkhorst, P., McDonald-Madden, E. \& Possingham, H. P. 2012. Acting fast helps avoid extinction. Conservation Letters 5 (4): 274-280. Doi: http://dx.doi.org/10.1111/j.1755-263X.2012.00239.x

Medina, F. M., Bonnaud, E., Vidal, E., Tershy, B. R., Zavaleta, E. S., Josh Donlan, C., Keitt, B. S., Le Corre, M., Horwath, S. V. \& Nogales, M. 2011. A global review of the impacts of invasive cats on island endangered vertebrates. Global Change Biology 17 (11): 3503-3510. Doi:_http://dx.doi.org/10.1111/ j.1365-2486.2011.02464.x

Millan, J. 2010. Feeding habits of feral cats Felis silvestris catus in the countryside of Majorca Island, Spain. Wildlife Biology in Practice 6(1): 32-38. Doi: http:// dx.doi.org/10.2461/wbp.2010.6.3

Miller, P. S., Boone, J. D., Briggs, J. R., LaWler, D. F., Levy, J. K., Nutter, F. B., Slater, M. \& ZAWISTOWSKI, S. 2014. Simulating free-roaming cat population management options in open demographic environments. PLoS ONE 9: e113553. Doi: http:// dx.doi.org/10.1371/journal.pone.0113553

Nelson, S. H., Evans, A. D. \& Bradbury, R. B. 2005. The efficacy of collar-mounted devices in reducing the rate of predation of wildlife by domestic cats. Applied Animal Behaviour Science 94(3): 273-285. Doi: http:// dx.doi.org/10.1016/j.applanim.2005.04.003

Nogales, M. \& Medina, F. M. 2009. Trophic ecology of feral cats (Felis silvestris f. catus) in the main environments of an oceanic archipelago (Canary Islands): An updated approach. Mammalian Biology 78(3): 169-181. Doi: http://dx.doi.org/10.1016/j. mambio.2008.10.002

Nogales, M., Vidal, E., Medina, F. M., Bonnaud, E., Tershy, B. R., Campbell, K. J., \& Zavaleta, E. S. 2013. Feral cats and biodiversity conservation: the urgent prioritization of island management. BioScience 63(10): 804-810. Doi: http://dx.doi. org/10.1525/bio.2013.63.10.7

Queiroz A., Alves P., Barroso I., Beja P., Fernandes M., Freitas L., Mathias M., Mira A., Palmeirim J. M., Prieto R., Rainho A., Rodrigues L., Santos-Reis M., SequeIRA M. 2005. Pipistrellus maderensis. In: Cabral M., Almeida J., Almeida P., Dellinger T., Ferrand de Almeida N., Oliveira M., Palmeirim J., Queiroz A., Rogado, L., Santos-Reis M. (Eds.). Livro vermelho dos vertebrados de Portugal. Instituto da Conservação da Natureza, Lisboa. 457-458. 
Rainho, A., Marques, J. T. \& Palmeirim, J. M. 2002. Os morcegos dos arquipélagos dos Açores e da Madeira: um contributo para a sua conservação. Instituto da Conservação da Natureza, Lisboa.

Rodríguez-Durán, A., Pérez, J., Montalbán, M. A. \& Sandoval, J. M. 2010. Predation by freeroaming cats on an insular population of bats. Acta Chiropterologica 12(2): 359-362. Doi:_http://dx.doi. org/10.3161/150811010X537945

Schulz, M. \& LumSDen, L. F. 2004. National recovery plan for the Christmas Island Pipistrelle Pipistrellus murrayi. Department of the Environment and Heritage.
Scrimgeour, J., Beath, A. \& Swanney, M. 2012. Cat predation of short-tailed bats (Mystacina tuberculata rhyocobia) in Rangataua Forest, Mount Ruapehu, Central North Island, New Zealand. New Zealand Journal of Zoology 39(3): 257-260. Doi: http://dx.doi. org/10.1080/03014223.2011.649770

Silva, L., Ojeda Land, E., RodríGuez Luengo, J. (eds.) 2008. Invasive terrestrial flora and fauna of Macaronesia. Top 100 in Azores, Madeira and Canaries. ARENA, Ponta Delgada, $546 \mathrm{pp}$.

Woods, M., McDonald, R. A. \& Harris, S. 2003. Predation of wildlife by domestic cats Felis catus in Great Britain. Mammal Review 33(2): 174-188. Doi: http:// dx.doi.org/10.1046/j.1365-2907.2003.00017.x 